\title{
Nasal Cavity and Paranasal Sinuses Cancer cN0 TNM Finding v8
}

National Cancer Institute

\section{Source}

National Cancer Institute. Nasal Cavity and Paranasal Sinuses Cancer cNO TNM Finding v8. NCI Thesaurus. Code C133050.

Nasal cavity and paranasal sinuses cancer with no metastasis to regional lymph nodes.

(from AJCC 8th Ed.) 